\title{
Mindfulness for patients with rheumatoid arthritis: systematic review
}

\author{
Mindfulness para pacientes com artrite reumatóide: revisão sistemática \\ Mindfulness para pacientes con artritis reumatoide: revisión sistemática
}

Received: 01/17/2021 | Reviewed: 01/20/2021 | Accept: 01/25/2021 | Published: 02/02/2021

Ledjane Neves Oliveira

ORCID: https://orcid.org/0000-0003-4771-3051 Federal University of São Carlos, Brazil E-mail: ledyneves@hotmail.com

André Telis De Vilela Araújo

ORCID: https://orcid.org/0000-0002-8656-870X

Federal University of Paraiba, Brazil

E-mail: andre_telis@globo.com

João Nelson Rodrigues Branco

ORCID: https://orcid.org/ 000-002-7552-4963 Federal University of São Paulo, Brazil E-mail: joao.nelson@terra.com.br

João Carlos Marchiori De Claudio

ORCID: https://orcid.org/0000-0003-0571-1058 Federal University of São Paulo, Brazil E-mail: joaocarlosmdec@gmail.com

Jeanne Liliane Marlene Michel

ORCID: https://orcid.org/0000-0002-2303-8242 Federal University of São Carlos, Brazil E-mail: jeanne.l.m.michel@gmail.com

Regimar Carla Machado

ORCID: https://orcid.org/0000-0001-6126-7663 Federal University of São Paulo, Brazil E-mail: regimar.carla@unifesp.br

\begin{abstract}
Objectives: To evaluate the effectiveness of mindfulness as a complementary therapy in patients with rheumatoid arthritis. Method: Protocol numbered CRD42017080108 on the PROSPERO platform. Manual searches and the Cochrane Collation assessment instrument were performed for systematic reviews in the databases CENTRAL, MEDLINE, PEDro, PsycoINFO, LILACS, Web of Science, clinical trials.gov, WHO-ICTRP and Open Gray. Randomized controlled trials were included without language restrictions or mindfulness temporality compared to placebo, psychotherapy or another equivalent strategy in patients with rheumatoid arthritis. Results: Four primary studies included (249 participants), which compared mindfulness with waiting lists, cognitive therapy and education. They presented better scores of disease activities, depressive symptoms, psychological distress, well-being, pain catastrophization, although they were classified as having a high risk of occurrence in at least one domain of the instrument used, presenting the need for robust clinical trials, proving the effectiveness of mindfulness in clinical practice. Conclusions: Beneficial effects of mindfulness in patients with rheumatoid arthritis are shown to present important results of changes in outcomes that affect the biopsychosocial dimensions in patients with. However, the evidence from the studies evaluated is of low quality, making it difficult to recommend intervention in clinical practice.
\end{abstract}

Keywords: Rheumatoid arthritis; Mindfulness; Complementary therapy.

\section{Resumo}

Objetivos: Avaliar a eficácia da mindfulness como terapia complementar em pacientes com artrite reumatoide. Método: Protocolada com o número CRD42017080108 na plataforma PROSPERO. Foi realizadas buscas manuais e o instrumento de avaliação da Colação Cochrane para revisões sistemática nas bases de dados CENTRAL, MEDLINE, PEDro, PsycoINFO, LILACS, Web of Science, ensaios clínicoss.gov, WHO-ICTRP e Open Grey. Foram incluídos ensaios clínicos randomizados sem restrições de idioma ou temporalidade do mindfulness em comparação com placebo, psicoterapia ou outra estratégia equivalente em pacientes com artrite reumatóide. Resultados: Quatro estudos primários incluídos (249 participantes), que compararam mindfulness com lista de espera, terapia cognitiva e educação. Apresentaram melhores escores das atividades da doença, sintomas depressivos, sofrimento psíquico, bemestar, catastrofização da dor, embora tenham sido classificados com alto risco de ocorrência em pelo menos um domínio do instrumento utilizado, apresentando a necessidade de ensaios clínicos robustos, comprovando a eficácia da atenção plena na prática clínica. Conclusões: Mostra-se efeitos benéficos da atenção plena em pacientes com artrite 
reumatoide por apresentar resultados importantes de mudanças nos desfechos que afetam as dimensões biopsicossociais em pacientes com. Porém, as evidências advindas dos estudos avaliados são de baixa qualidade, dificultando a recomendação da intervenção na prática clínica.

Palavras-chave: Artrite reumatoide; Mindfulness; Terapia complementar.

\section{Resumen}

Objetivos: Evaluar la efectividad del mindfulness como terapia complementaria en pacientes con artritis reumatoide. Método: Protocolo numerado CRD42017080108 en la plataforma PROSPERO. Se realizaron búsquedas manuales y el instrumento de evaluación Cochrane Collation para revisiones sistemáticas en las bases de datos CENTRAL, MEDLINE, PEDro, PsycoINFO, LILACS, Web of Science, Clinical Trial.gov, WHO-ICTRP y Open Gray. Se incluyeron ensayos controlados aleatorios sin restricciones de idioma o temporalidad de atención plena en comparación con placebo, psicoterapia u otra estrategia equivalente en pacientes con artritis reumatoide. Resultados: Se incluyeron cuatro estudios primarios (249 participantes), que compararon la atención plena con listas de espera, terapia cognitiva y educación. Presentaron mejores puntajes de actividades de la enfermedad, síntomas depresivos, malestar psicológico, bienestar, catastrofización del dolor, aunque fueron clasificados como de alto riesgo de ocurrencia en al menos un dominio del instrumento utilizado, presentando la necesidad de ensayos clínicos robustos, que demuestren la efectividad del mindfulness en la práctica clínica. Conclusiones: Se ha demostrado que los efectos beneficiosos de la atención plena en pacientes con artritis reumatoide presentan resultados importantes de cambios en los resultados que afectan las dimensiones biopsicosociales en pacientes con. Sin embargo, la evidencia de los estudios evaluados es de baja calidad, lo que dificulta recomendar una intervención en la práctica clínica.

Palabras clave: Artritis reumatoide; Mindfulness; Terapia complementaria.

\section{Introduction}

Rheumatoid arthritis (RA) targets $1 \%$ of the global population, being it characterized as an autoimmune systemic disease with chronic progressive inflammation, which causes deformity and destruction of articulations, causing a negative impact in the autonomy for performance of daily activities, quality of life, leading to cardiovascular diseases as well as in the lungs, psychological disorders, and increases in mortality rates (Bértolo et al, 2009; Myasoedova et al, 2010; Singh et al, 2015).

The correlation of genetic and environmental factors is reversed in a cascade of immunologic reactions mediated by the production of autoinducers, activation of T cells, tumoral necrosis factor (TNF- $\alpha$ ) and interleukin 6 (IL-6), which cause synovitis, harms in articulations and in bones leading to pain, inability, and emotional, economic, and social challenges (Gibofsky, 2012). The standard treatment for RA is composed by modifying medicaments throughout the progress of the disease, conventional synthetic and biological drugs, though there has been a crescent search of transcendent complementary therapeutic interventions to the biologic sphere, which includes the individual as a holistic and singular being (Bértolo et al, 2009; Demarzo, 2011).

Mindfulness has been highlighted as a possible promising complementary therapy, once it promotes the reeducation of thoughts through training, as well as enabling the change of habits and perspective toward the way in which the experiences of the disease and pain are lived, enabling the individuals to face the adversities under a new perspective, without fearing of being the motivational agent of their own behavior (Young, 2011)

A study carried out with women diagnosed with breast cancer in a Mindfulness Based Stresse Redution (MBSR) program has stated that the intervention group presented decrease in the cortisol plasmatic level during the morning, while the same change has not been noticed in the control group. An immune function evaluation was done in both groups, and the MBSR group's participants have presented homeostasis restauration between Natural Killers cells (NKCA) and cytokines, while in the control group the immune irregularity persisted. It has been concluded that high levels of NKCA in patients with cancer have indicated a good prognostic, since these cells identify and destruct genotoxic cells, and also with damaged DNA (Witek-Janusek et al, 2008).

Systematic reviews have shown that the results of mindfulness therapy have been fruitful in the progress of mental 
health, reduction of stress, anxiety, and depression, besides contributing positively with the psychological well-being of healthy participants (Fjorback et al, 2011; Chiesa \& Serretti, 2009). Thus, considering the relevance of mindfulness, the objective of the present systematic review was to assess the effectiveness of mindfulness as a complementary therapy for patients with rheumatoid arthritis

\section{Methodology}

\section{Design}

This is a systematic review of randomized clinical trials (RCTs), guided by recommendations from Cochrane Handbook for systematic Review of Interventions. Prisma Recommendation (Preferred Reporting Items for Systematic Review and Meta-Analyses: the PRISMA statement) was used in order to guide this review (see additional file 1) (Liberati et al, 2009).

The protocol of this study was registered at the International Prospective Register of Systematic Reviews (PROSPERO), entitled: "Mindfulness for rheumatoid arthritis patients: a systematic review", and register: CRD42017080108, $18 / 12 / 17$.

PICO strategy has been used to structure the research question, in which P (Patient) relates to the patients with rheumatoid arthritis, I (Intervention) for the use of mindfulness;C (Comparison) to the use of sham, placebo, and other therapies; and $\mathrm{O}$ (Outcomes), divided in primary: handling the symptoms, improvement in quality of life, and secondary: patient's satisfaction, reduction in pain, and hardness in articulations (Stone, 2002).

Based on this structure, the following question was elaborated: Mindfulness is more effective than sham, yoga, and another equivalent strategy for individuals with rheumatoid arthritis?

\section{Inclusion and exclusion criteria}

Studies performed in adults, individuals with rheumatoid arthritis were included, while those with participants under 18 and other rheumatic diseases were excluded.

\section{Search strategy}

An intensive search in electronic databases were done by two reviewers, independently. There has been no restriction of which language nor year of publication, considering published and non-published studies, reports, reviews, and studies in progress.

The electronic databases used for identifying the studies were:Cochrane Central Register of Controlled Trials (CENTRAL), via Wiley Cochrane Library, Medical Literature Analysis and Retrieval System Online (MEDLINE), via PubMed. PhysiotherapyEvidenceDatabase (PEDro), The PsycINFODatabase-American PsychologicalAssociation (APA), Literatura Latino Americana e do Caribe em Ciências da Saúde (LILACS), via Biblioteca Virtual em Saúde (BVS), Web of Science.

The search strategies in the databases were highly sensible for identifying randomized controlled trial and have used controlled and non-controlled descriptors combined with booleanoperators, of proximity and truncations, which have been presented in a peculiar search protocol (see additional file 2) for each database (Lefebvre, Manheimer \& Glanville, 2011).

Newly concluded studies have been assessed, or in progress, with register at Clinical Trials Registry Platform (ICTRP), of the World Health Organization (WHO), available at: http://apps.who.int/trialsearch/default.aspx, and at ClinicalTrials.gov (clinicaltrials.gov). Besides that, the grey literature can be accessed through Open Grey. Manual searches were done in the list of reference of important papers in order to identify randomized clinical trials non-recovered in searches in databases, having annuals of national and international events assessed about the subject: 34th Brazilian Congress in 
Rheumatology, World Congress Integrative Medicine 2017, European Federation for Complementary and Alternative Medicine, British Society for Rheumatology, Annals of Rheumatic Diseases- BMJ Journals, Annals of World Congress Integrative Medicine \& Health 2017, Brazilian Society of Rheumatology, Pan American League of Associations for Rheumatology, American College of Rheumatology.

\section{Selection of studies and data extraction}

The selection of papers was performed in three stages by two reviewers, independently.

In the first stage the titles/abstracts were analyzed considering the research question, and inclusion and exclusion criteria of the protocol of this systematic review.

In the second stage the selected studies of the first stage were analyzed fully for its eligibility through a paper selection instrument, elaborated according to the inclusion and exclusion criteria of this review and according to the Consolidated Standards of Reporting Trials (Consort), instrument used to report randomized clinical trials (Hopewell et al, 2008).

In the third stage the selected articles were analyzed fully, this time having data extraction forms, based on recommendations from Cochrane Handbook, an evaluation instrument by the Cochrane Collaboration (Higgins \& Green, 2012).

A reviewer has performed the data extraction from the articles included in the review, and another senior reviewer has checked rigorously this stage. Predefined forms were used, elaborated according to recommendations from the Cochrane Collaboration, with the following items: title, authors, year, journal, location of the study, eligibility criteria, design of the study, allocation method,allocation concealment, masking, risk of bias, type of analysis, number of participants,interventions, comparisons, outcomes performed, time of follow-up, follow-up, and results. The disagreements were solved by consensus, or through the assessment by a third reviewer. When There was incompleteness of the data in the articles included in the review, the authors were contacted for obtaining additional information. It has been stablished contact with an author from New Zealand in order to complete the extraction of information of the study.

\section{Study quality appraisal}

The risk evaluation of the bias for each study included was performed by the use of an instrument available by the Cochrane Collaboration, which owns seven domains: generation of the allocation sequence, secrecy of allocation, masking of participants and professionals, masking of evaluators of outcomes, outcomes of incomplete data, other sources of bias, for each domain it has been attributed a low, uncertain, or high risk of bias (Higgins \& Green, 2012).

\section{Results}

\section{Study settings and participants}

The initial search has raised 5.495 references spread in manual search and in databases: 19 in PsycoInfo, 565 in Central, 101 in PEDro, 25 in clinicaltrials.gov, 550 in Who ICTRP, 808 in Medline, 126 in Web of Science, 738 in Lilacs, 259 in Open Grey, 1.066 in Annals of rheumatic diseases. In electronic databases, 4.258 references were recovered, of which 1.237 were done by manual search.

After removing 689 doubled references, the titles and abstracts of 4.806 references were read, of which 4.800 were excluded for not meeting the inclusion criteria. The last 6 references composed by 4 complete studies and 2 protocols were analyzed fully. The Figure 1 details the selection and filtering process of the studies: 
Research, Society and Development, v. 10, n. 2, e2610212047, 2021

(CC BY 4.0) | ISSN 2525-3409 | DOI: http://dx.doi.org/10.33448/rsd-v10i2.12047

Figure 1 - Prisma Flowdiagram, São Paulo, 2021.

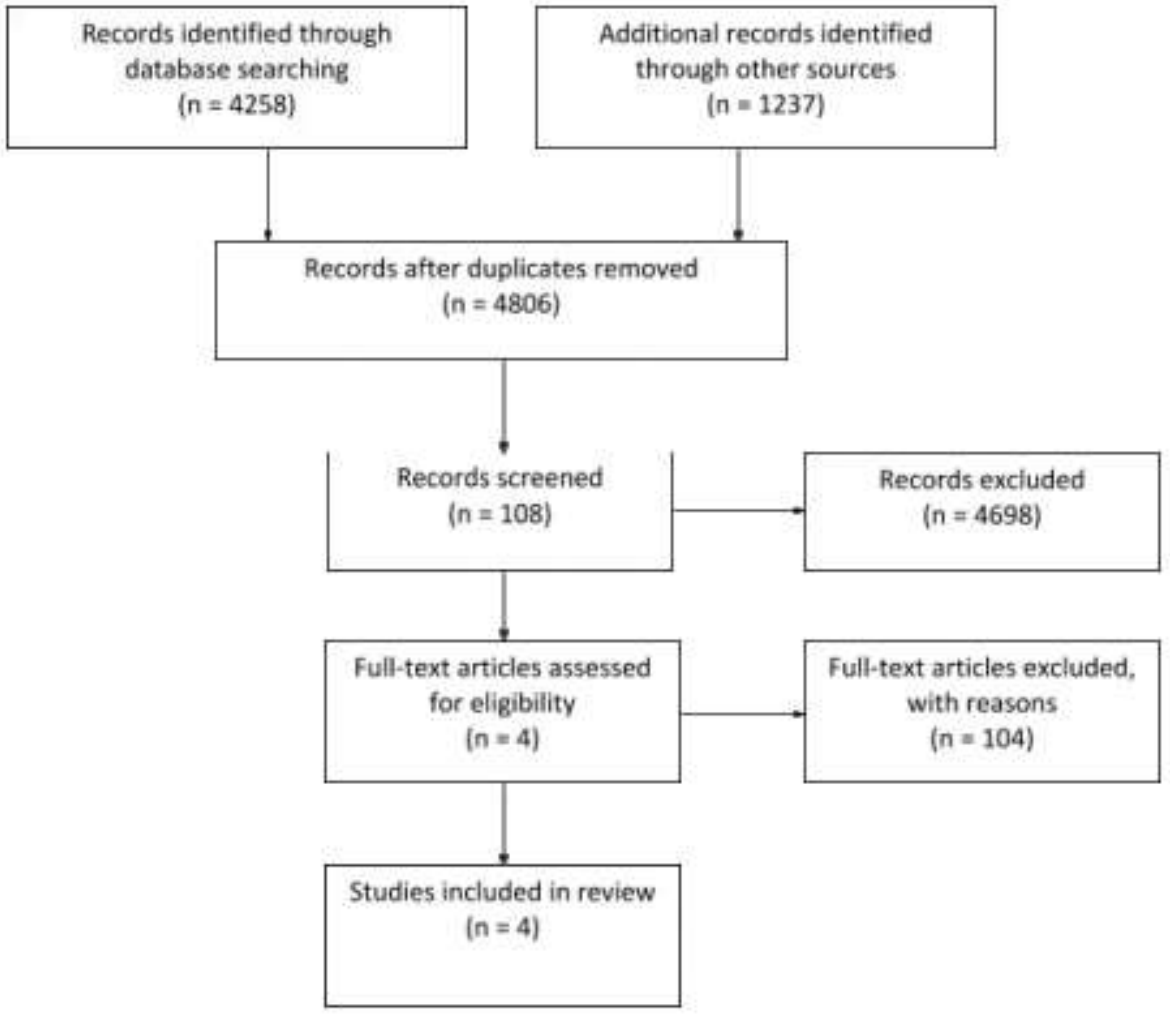

Source: Authors.

Four finalized studies included composed a total of 249 participants, diagnozed with rheumatoid arthritis, mainly female, being 76,3\% with ages ranging from 18 to 75 years old.

These studies are heterogeneous in aspects related to the number and duration of sessions of mindfulness, to the comparators, outcomes, statistic tests performed and follow-up.

The main characteristics included are presented in the Table 1 below: 
Table 1 - Characteristics of the studies included, São Paulo, 2021.

\begin{tabular}{|c|c|c|c|c|}
\hline Studies & Fogarty et al, 2015 & Davis et al, 2015 & Pradhan et al, 2007 & Zautra et al, 2008 \\
\hline $\begin{array}{l}\text { Clinical } \\
\text { register }\end{array}$ & ACTRN12610000485033 & NCT00475111 & NCT00071292 & NCT00475111 \\
\hline $\begin{array}{l}\text { Location of } \\
\text { the studies }\end{array}$ & Auckland, New Zealand & $\begin{array}{l}\text { Arizona, the } \\
\text { United States }\end{array}$ & $\begin{array}{l}\text { Maryland, the United } \\
\text { States }\end{array}$ & $\begin{array}{l}\text { Arizona, the } \\
\text { United States }\end{array}$ \\
\hline Population & $\mathrm{N}=42$ & $\mathrm{~N}=144$ & $\mathrm{~N}=63$ & $\mathrm{~N}=144$ \\
\hline Intervention & $\begin{array}{l}\text { 8-week program of MBSR, } \\
\text { developed by the University of } \\
\text { Massachusetts }\end{array}$ & $\begin{array}{l}\text { Cognitive } \\
\text { Therapy for pain } \\
\text { mindfulness } \\
\text { meditation }\end{array}$ & $\begin{array}{l}\text { 8-week program of } \\
\text { MBSR }\end{array}$ & $\begin{array}{l}\text { Cognitive therapy } \\
\text { for pain } \\
\text { mindfulness } \\
\text { meditation }\end{array}$ \\
\hline Control & $\begin{array}{l}\text { Waiting list: control group } \\
\text { agreed in joining the MBSR } \\
\text { program after collecting the } \\
\text { data }\end{array}$ & $\begin{array}{l}\text { Education on } \\
\text { Arthritis (Group } \\
\text { E) }\end{array}$ & waiting list & $\begin{array}{l}\text { Education on } \\
\text { Arthritis }\end{array}$ \\
\hline Medications & $\begin{array}{l}\text { Methotrexate } \\
\text { Prednisone }\end{array}$ & $\begin{array}{l}\text { there is no } \\
\text { description of } \\
\text { medications in } \\
\text { the study }\end{array}$ & $\begin{array}{l}\text { Disease-modifying } \\
\text { antirheumatic drugs } \\
\text { (DMARDS) } \\
\text { Corticosteroid } \\
\text { Biologic response } \\
\text { modifiers } \\
\text { Nonsteroidal anti- } \\
\text { inflammatory drug } \\
\text { (NSAID) }\end{array}$ & $\begin{array}{l}\text { there is no } \\
\text { description in the } \\
\text { study }\end{array}$ \\
\hline
\end{tabular}

Source: Authors.

The Table 2 presents the synthesis of results of studies included in the review. 
Table 2 - Main results found in the studies, São Paulo, 2021.

\begin{tabular}{|c|c|c|}
\hline Studies & Outcomes & Results \\
\hline Fogarty et al 2015 & $\begin{array}{l}\text { Disease activity score - } 28 \text { (DAS } \\
\text { 28) which includes: number of } \\
\text { sensible and swollen articulations, } \\
\text { level of reactive C protein (PCR), } \\
\text { morning boldness, pain }\end{array}$ & $\begin{array}{l}\text { MBSR group: reduction of DAS- } \\
28-P C R(p<0.01) \text {, right after the } \\
\text { intervention and during follow-up. } \\
\text { Reduction in counting } \\
\text { articulations in pain }(\mathrm{p}<0.02) \text {, pain } \\
\text { score }(\mathrm{p}<0.02) \text { and reduction in } \\
\text { morning boldness }(\mathrm{p}<0.03) \text {. }\end{array}$ \\
\hline Davis et al 2015 & $\begin{array}{l}\text { Fatigue } \\
\text { Morning inability } \\
\text { Interpersonal distress, } \\
\text { catastrophizing, and pain control. } \\
\text { Anxiousand serene affection }\end{array}$ & $\begin{array}{l}\text { Mindfulness group has produced } \\
\text { substantial benefits that the } \\
\text { cognitive therapy group for pain } \\
\text { and education on fatigue }(\mathrm{ps}<.02) \text {, } \\
\text { in morning inability }(\mathrm{p}<.02) \text {, } \\
\text { improvement in distress in anxious } \\
\text { affection ( } \mathrm{ps}<0.04) \text {, in } \\
\text { catastrophizing ( }<<.02) \text {, pain } \\
\text { control ( }<<.02) \text {, and improvement } \\
\text { in serene affection ( }<<0.03) \text {. In } \\
\text { often depressive individuals, } \\
\text { mindfulness was more effective } \\
\text { than cognitive therapy and } \\
\text { education (ps<.0003). }\end{array}$ \\
\hline Zautra et al 2008 & $\begin{array}{l}\text { Pain } \\
\text { Positive and negative affection } \\
\text { Effectiveness of facing pain } \\
\text { Pain control } \\
\text { Depression } \\
\text { DA score } 28 \\
\text { IL-6 }\end{array}$ & $\begin{array}{l}\text { Mindfulness group has reported } \\
\text { greater levels of pain control } \\
(\mathrm{p}<.01) \text { than education group } \\
(\mathrm{p}<.02) \text { and has demonstrated an } \\
\text { increase less noticeable in } \\
\text { catastrophizing associated to the } \\
\text { daily pain episode }(\mathrm{p}<.004) \text {. } \\
\text { There has been an improvement in } \\
\text { the inability and fatigue ( }<<.008) \text {, } \\
\text { in distress episodes, and changes } \\
\text { in serene and anxious affections } \\
\text { ( }<<.03) \text {. } \\
\text { There has been no reduction in } \\
\text { serum levels of IL- } 6 \text { for } \\
\text { mindfulness group. }\end{array}$ \\
\hline Pradhan et al 2007 & $\begin{array}{l}\text { Psychological stress } \\
\text { (DAS 28) } \\
\text { Well-being } \\
\text { Attention state }\end{array}$ & $\begin{array}{l}\text { There has been no significant } \\
\text { difference in outcome after } 2 \\
\text { months of intervention }(\mathrm{p}=0.52) \text {. } \\
\text { Depressive symptoms }(\mathrm{p}=0,52 ; \\
\text { psychological distress }(\mathrm{p}=0.27) \text {; } \\
\text { well-being }(\mathrm{p}=0.14) \text {; attention } \\
\text { state ( } \mathrm{p}=0.57) \text {; DAS- } 28 \text { ( } \mathrm{p}=0.31) \text {. } \\
\text { After } 6 \text { months, there has been an } \\
\text { improvement associated to the } \\
\text { intervention }(\mathrm{p}<0.03) \text {; depressive } \\
\text { symptoms }(0.05) \text {. }\end{array}$ \\
\hline
\end{tabular}

Source: Authors.

For the generation domain of the randomized sequence, this evaluation has shown that all the studies were classified as having low risk of bias of selection.

Regarding the allocation secrecy, just two studies (Fogarty et al, 2015; Pradhan et al, 2007) were classified as having low risk of bias of selection, while the others presented an uncertain risk for this domain (Davis et al, 2015; Zautra et al, 2008). About the blinding domain of participants and personal, two studies (Fogarty et al, 2015; Pradhan et al, 2007) have presented high risk of bias, with none presenting low bias risk of performance (Davis et al, 2015; Zautra et al, 2008). 
In blinding the outcome evaluators, the study (Fogarty et al, 2015) presented a low risk, and the study (Pradhan et al, 2007) a high risk of bias of detection. Two studies had an uncertain risk of bias for this domain.

In the incomplete outcome data domain three studies were found (Pradhan et al, 2007; Davis et al, 2015; Zautra et al, 2008) presenting low risk of bias of attrition, once all losses were reported in a transparent way. There was only one study that has not reported losses (Fogarty el. al 2015).

In the domain related to the selective reporting, only the studies (Davis et al, 2015; Zautra et al, 2008) had a low risk of bias of reporting. In the study (Fogarty el. al 2015), the outcomes depression, anxiety, and well-being were present in the protocol of the study, no being reported in the original article. It is highlighted that in the study (Pradhan et al, 2007) the outcomes were not described in the protocol of the study.

The"high risk of bias" present in many domains of the evaluation limits the robustness of the body of evidences coming from these trials, once the bias corresponds to the systematic error that impairs the truthfulness of the studies (Higgins \& Green, 2012).

The assessment of risk of bias was done through an instrument from the Cochrane Collaboration and Figure 2 presents the summary of risk of bias for each domain.

Figure 2 - Risk of bias summary: review authors' judgements about each risk of bias item for each included study, São Paulo, 2021.

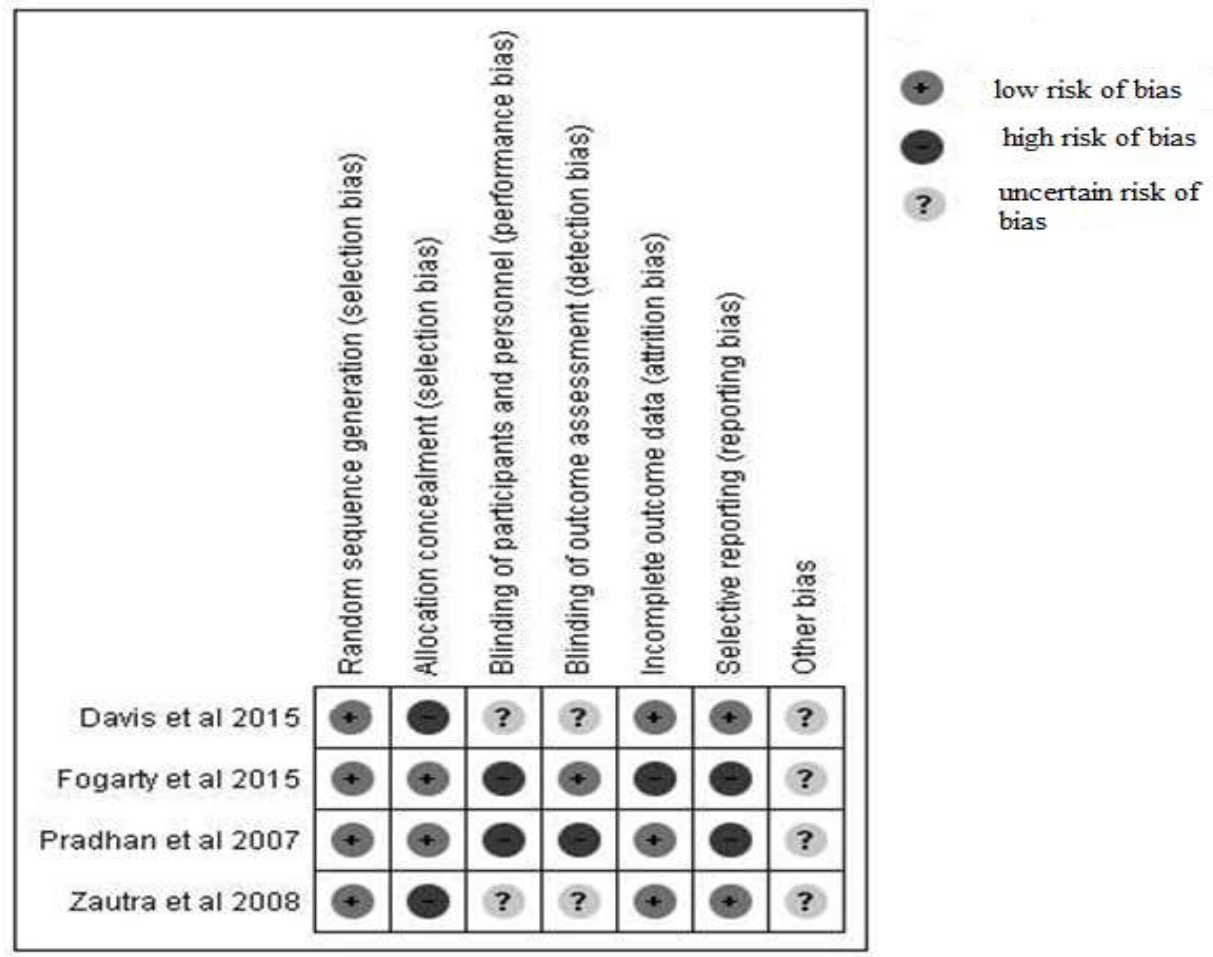

Source: Authors.

\section{Discussion}

This systematic review had the purpose to evaluate the effectiveness of mindfulness as an integrative practice for patients with rheumatoid arthritis by presenting important results to changes in several outcomes, such as improvement in Disease Activity Scores (DAS-28- CRP), morning boldness, pain, global evaluation of the patient, depressive symptoms, psychological distress, well-being, improvements in positive and negative affections, reduction in counting inflamed 
articulations, reactivity to stress and catastrophizing pain, improvements in reported pain, fatigue, morning disfunction, anxious and serene affections, raising the attention of numerous researchers in the last years.

In agreement with the data from the literature, the randomized clinical trial performed with 91 women presenting fibromyalgia has shown that MBSR has not changed significantly the parameters of pain, physical functionality nor cortisol. Nevertheless, the analyses have stated that this therapy has minimized significantly the noticed stress, sleeping disturbances, and seriousness of symptoms, with gains kept during the follow-up (Cash et al, 2015).

A study performed with 46 patients with Systemic lupus erythematosus in which the goal was to determine the effectiveness of the therapy with mindfulness has observed a reduction in outcomes such as depression, anxiety, somatization, and increase in quality of life of patients, clarifying that this intervention enables them to have consciousness of their corporal sensations, thoughts, and emotions without judgement, allowing a reduction and elimination of negative thoughts, and enhancing quality of life (Solati et al, 2017).

A clinical trial included in the sample of this review with 42 patients with rheumatoid arthritis compared MBSR with the waiting list, and have shown improvement in DAS 28-CRP, morning boldness, pain, and global evaluation of the patient right after the intervention, and after 4 and 6 months. The Disease Activity Score in 28 joints - C-reactive protein (DAS 28CRP) was proposed to assess the activity of RA in clinical practice, an index that takes into consideration the number of articulations in pain and swelling, the biomarker for reactive protein $\mathrm{C}$, and the global evaluation of the patient. It is highlighted that the presence of pain, edema in articulations, morning stiffness and reactive protein $\mathrm{C}$ are indicators of an inflammatory process, once through autoimmune reactions of cells $\mathrm{T}$ and $\mathrm{B}$ and inflammatory cytokines are produced in the synovial membrane causing the signs and symptoms of RA (Fogarty et al, 2015; Van der Heijde et al, 1990; Firestein, 2003).Other study (Fogarty et al, 2015) has stated a decrease of these variables measured by the inflammatory process in the intervention group with MBSR, being this fact explained by the activation of ordered mindfulness at the pre-frontal cortex, brain regioninvolved with memory, attention, decision making, planning, social relations, and flexibility in behavior (Chiese, Serreti, 2010; Damasio, 2000)This brain region can be harmed by chronic stress, once there is a reduction in volume in superficial areas due to the presence of increased levels of corticosterone produced in cascade prior to stress (Cerqueira, Almeida \& Sousa, 2008). It is known that the intervention with mindfulness can contribute to the decrease in levels of stress and their components reducing signs and symptoms related to the inflammation, being an example one mentioned in a study that has induced the cutaneous inflammatory response through a topical cream of capsaicin stating that the intervention group with mindfulness had reduced the development of the inflammation with a more satisfactory performance in terms of the hypothalamus-pituitary-adrenal axis, directly involved in the physiology of stress, besides having a more intense drop of cortisol after training, when compared to the pre-training of those in the control group(Rosenkranz et al, 2013).

A study done with 80 participants in which the intervention was meditation, it has been stated that in their analysis in the experimental group, there were higher levels of IgA, and lower ones of cortisol in saliva, after an acute stressor agent, showing this way a strengthening of the immunologic system and improvement in reaction to stress (Yi-Yuan, 2007).

A clinical research included in this review has shown no significant difference in the activity of the disease in the MBSR group and waiting list at 2 months after the intervention. After 6 months, however, it has been stated improvements in depressive symptoms, stress, and psychological well-being (Pradhan et al, 2007).

The authors of this study affirm that the reason for the absence of effects at 2 months is not clear, once the intervention of 8 weeks with MBSE has been presented as able to reduce trustworthily outcomes such as depressive symptoms, anxiety, and stress (Grossman et al, 2004). The authors state that there has probably been a floor effect in their study, with participants at not so high stages of depression nor psychological impairments. The level of psychological suffering was $45 \%$ lower in this study than the other that has used the same instrument for evaluation and basal level of psychological anguish 
being 72\% higher (Bardwell et al, 2002). The floor effect can impair the internal validity of a clinical trial, since it affects the visible differences, relevant to the effect of clinical practice intervention. Scales for assessing the outcomes must be trustworthy, being tested in pilot studies, what has happened with this study (Pradhan et al, 2007), though the scales may have had a good construction validity, there were characteristics that were not well distributed within the population (Fogg \& Gross, 2000). After 6 months, however, it has been noticed improvements in depressive symptoms, stress, and psychological wellbeing. Mindfulness increases the psychological well-being, once it stimulates cognitive activities for controlling attention, reducing rumination, increasing concentration, and optimizing memory, favoring emotional regulation (Chambers, Lo, \& Allen, 2008). This practice contributes, then, to the development of non-reactivity, and mitigating depression symptoms (Teasdale et al, 2002)

The systematic review and its metanalysis that investigated the effect of meditation programs on stress and anxiety has presented a reduction in anxiety, depression, and pain with moderate levels of evidence, and light improvements in stress and affliction in mental health. The quality of life had low evidence when compared to non-specific active controls in groups that had taken mindfulness meditation as intervention (Goyal et al., 2014).

Randomized clinical trial with an intervention based on mindfulness, and the control group receiving care has shown that the number of participants with severe or chronic psychological stress was reduced from 13 to 2 in comparison with the reduction from 10 to 8 after 1 year, in the control group performed with people with rheumatic inflammatory diseases. The treatment has presented effectiveness in pain and fatigue, which has increased in the post treatment for the 12 following months. The study evidenced the importance of expressing emotions, once the inhibition has been associated to the bad adaptation to chronic diseases. Mindfulness contributes so these life experiences are lived in a way so it can reduce the impact of stress and emotions such as fear, anger, and guilt, which can contribute to the appearing of pain and fatigue (Zangi et al, 2012).

A systematic review with metanalysis concluded that the therapies based on acceptance has low to average effects on mental health of patients with chronic pain, which are equivalent to the behavior cognitive therapy, though due to the relevant function of acceptance and mindfulness in the adaptation to chronic disease, being it promising to the development of studies that involve interventions that integrate MBSR with behavioral therapy (Veehof et al, 2011).

A metanalysis conducted to examine the effectiveness of the therapy with mindfulness in mental health of people with chronic disease found that MBSR has shown slight effects over depression, anxiety, and affliction in people with chronic diseases. Nonetheless, the authors state that this result can be undervalued due to the ceiling effect of studies in which the independent variable stops affecting the dependent variable. In order to solve this problem, the authors recommend new studies in which participants with moderate to high levels of anxiety and depressions could be included, in order to prevent the ceiling effect, besides including measurements for the follow-up (Bohmeijer et al, 2009).

A narrative review study presents the importance of psychotherapeutic approaches while treating people with rheumatoid arthritis, highlighting the importance in controlling the disease's activity with traditional pharmacotherapy, however, it is indispensable the development of strategies for facing pain, and chronic distress, which can be triggered by this disease. Anxiety and depression, for instance, are common symptoms in patients with rheumatoid arthritis, and it can impair the effectiveness of the pharmacologic treatment. Thus, this study has highlighted the importance of strengthening the power of mental resilience, and in believing that mindfulness can collaborate with this outcome (Graninger, 2015).

A study performed with 43 participants with rheumatoid arthritis had as its goal to examine the correlation between the positive affection with a resilience element, in the ratio between pain and negative affection. It has been concluded that positive affection is an important component for the development of resilience, and it contributes to minimize oscillations in the disease's activity. This way, the mindfulness practice can be a source of production of positive affection, being possible to 
state this process as simply "paying attention" to the present moment, facilitating the growth of positive affection (Strand, 2006; Brown \& Ryan, 2004).

In agreement with these findings, the study included in the sample of this review compared mindfulness education and cognitive therapy for patients with rheumatoid arthritis. The participants with recurrent depression had noticeable improvements in the positive and negative affection, and in counting inflamed articulations. Mindfulness has shown noticeable modifications in pain, reactivity to stress, and catastrophizing pain after the intervention, when compared to the cognitive therapy and education (Zautra et al, 2008).

In a post hoc analysis above mentioned, mindfulness has presented greater changes in catastrophizing, morning boldness, fatigue, serene and anxious affection compared to the cognitive therapy and education. In patients with recurrent depression, mindfulness presented significant improvements in fatigue when compared to experiences full of catastrophizing, anxiety, pain, fatigue, which contributes so these life experiences be examined with acceptance, free from judgments, and rationality, thus minimizing the reactivity regarding adverse situations (Davis et al, 2015; Garland et al, 2012).

Regarding the evaluation of risk of bias, the studies were classified as having high risk, or uncertain in several domains such as allocation concealment, blinding of participants, incomplete outcomes, selective reporting of outcome. Thus, all these aspects contribute to evidences of limited quality that do not offer forceful and trustworthy responses about the effect of the intervention with mindfulness in patients with rheumatoid arthritis.

It is highlighted the importance of randomized clinical trials well outlined and conducted with methodological rigor are indispensable, so that it is possible to produce solid evidences, robust regarding intervention mindfulness to patients with rheumatoid arthritis.

Some variables are relevant and should be considered for future clinical trials, diagnosis timing, and seriousness of the disease, the identification of characteristics of participants such as personality, perception of the disease, their facing styles, once these can become responsive to the psychological interventions.

A limiter factor in this study was the type of outcome assessed in trials included in the review because they are subjective. Unfortunately, outcomes reported by patients or dependent on judgment of an observer are subjected to bias due to the occurrence in inappropriate blinding (Moustagaard et al, 2014).

Confirming what has been exposed previously, another research that performed sub-studies within the same clinical trial, with and without blinding was able to check a significant exaggeration in sizes of effects due to the blinding gap of the participants (Hrobjartsson et al, 2014).

\section{Conclusion}

This revision has shown beneficial effects of mindfulness by presenting important results of changes in outcomes that affect biopsychosocial dimensions in patients with rheumatoid arthritis. However, the evidences coming from the studies assessed are of low quality, impairing the recommendation of the intervention in clinical practice.

\section{References}

Bardwell, W. A., Nicassio, P. M., Weisman, M. H., Gevirtz, R., \& Bazzo, D. (2002). Rheumatoid Arthritis Severity Scale: a brief, physician-completed scale not confounded by patient self-report of psychological functioning. Rheumatology (Oxford, England), 41(1), 38-45. https://doi.org/10.1093/rheumatology/41.1.38. 
Brown, K. W., \& Ryan, R. M. (2004). Perils and promise in defining and measuring mindfulness: Observations from experience. Clinical Psychology: Science and Practice, 11(3), 242-248. https://doi.org/10.1093/clipsy.bph078

Cash, E., Salmon, P., Weissbecker, I., Rebholz, W. N., Bayley-Veloso, R., Zimmaro, L. A., Floyd, A., Dedert, E., \& Sephton, S. E. (2015). Mindfulness meditation alleviates fibromyalgia symptoms in women: results of a randomized clinical trial. Annals of behavioral medicine: a publication of the Society of Behavioral Medicine, 49(3), 319-330. https://doi.org/10.1007/s12160-014-9665-0

Cerqueira, J. J., Almeida, O. F. X., \& Sousa, N. (2008). The stressed prefrontal cortex. Left? Right! Brain, Behavior, and Immunity, 22(5), 630-638. https://doi.org/10.1016/j.bbi.2008.01.005

Chambers, R., Lo, B. C. Y., \& Allen, N. B. (2008) The Impact of Intensive Mindfulness Training on Attentional Control, Cognitive Style, and Affect. Cogn Ther Res 32, 303-322. https://doi.org/10.1007/s10608-007-9119-0

Chiesa, A., \& Serretti, A. (2010). A systematic review of neurobiological and clinical features of mindfulness meditations. Psychological medicine, 40(8), 1239-1252. https://doi.org/10.1017/S0033291709991747

Chiesa, A., \& Serretti, A. (2009). Mindfulness-based stress reduction for stress management in healthy people: a review and meta-analysis. Journal of alternative and complementary medicine (New York, N.Y.), 15(5), 593-600. https://doi.org/10.1089/acm.2008.0495

Damasio, A. R (2000). The fabric of the mind: a neurobiological perspective. Prog. Brain Res. 126: 457- 467. https://doi.org/10.1016/S0079-6123(00)26029-9.

Davis, M. C., Zautra, A. J., Wolf, L. D., Tennen, H., \& Yeung, E. W. (2015). Mindfulness and cognitive-behavioral interventions for chronic pain: differential effects on daily pain reactivity and stress reactivity. Journal of consulting and clinical psychology, 83(1), 24-35. https://doi.org/10.1037/a0038200

Demarzo, M. M. P. (2011). Meditation applied to health. PROMEF. https://cursos.atencaobasica.org.br/sites/default/files/promef_meditacao_2011.pdf.

Firestein G. S. (2003). Evolving concepts of rheumatoid arthritis. Nature, 423(6937), 356-361. https://doi.org/10.1038/nature01661

Fjorback, L. O., Arendt, M., Ornbøl, E., Fink, P., \& Walach, H. (2011). Mindfulness-based stress reduction and mindfulness-based cognitive therapy: a systematic review of randomized controlled trials. Acta psychiatrica Scandinavica, 124(2), 102-119. https://doi.org/10.1111/j.1600-0447.2011.01704.X

Fogarty, F. A., Booth, R. J., Gamble, G. D., Dalbeth, N., \& Consedine, N. S. (2015). The effect of mindfulness-based stress reduction on disease activity in people with rheumatoid arthritis: a randomised controlled trial. Annals of the rheumatic diseases, 74(2), 472-474. https://doi.org/10.1136/annrheumdis-2014205946

Fogg, L., \& Gross, D. (2000). Threats to validity in randomized clinical trials. Research in nursing \& health, 23(1), 79-87. https://doi.org/10.1002/(sici)1098240x(200002)23:1<79::aid-nur9>3.0.co;2-r

Garland, E. L., Gaylord, S. A., Palsson, O., Faurot, K., Douglas Mann, J., \& Whitehead, W. E. (2012). Therapeutic mechanisms of a mindfulness-based treatment for IBS: effects on visceral sensitivity, catastrophizing, and affective processing of pain sensations. Journal of behavioral medicine, 35(6), 591-602. https://doi.org/10.1007/s10865-011-9391-z

Gibofsky A. (2012). Overview of epidemiology, pathophysiology, and diagnosis of rheumatoid arthritis. The American journal of managed care, 18(13 Suppl), S295-S302

Goyal, M., Singh, S., Sibinga, E. M., Gould, N. F., Rowland-Seymour, A., Sharma, R., Berger, Z., Sleicher, D., Maron, D. D., Shihab, H. M., Ranasinghe, P. D., Linn, S., Saha, S., Bass, E. B., \& Haythornthwaite, J. A. (2014). Meditation programs for psychological stress and well-being: a systematic review and meta-analysis. JAMA internal medicine, 174(3), 357-368. https://doi.org/10.1001/jamainternmed.2013.13018

Graninger M. (2015). Verhaltenstraining als zusätzlicher Therapieansatz bei rheumatoider Arthritis [Behavioral training as additional therapy approach for rheumatoid arthritis]. Zeitschrift fur Rheumatologie, 74(7), 579-583. https://doi.org/10.1007/s00393-014-1554-1

Grossman, P., Niemann, L., Schmidt, S., \& Walach, H. (2004). Mindfulness-based stress reduction and health benefits. A meta-analysis. Journal of psychosomatic research, 57(1), 35-43. https://doi.org/10.1016/S0022-3999(03)00573-7

Higgins, J. P. T., \&Green, S. (2012). Cochrane handbook for systematic reviews of interventions version 5.0.2 [internet]. The Cochrane Collaboration. www.cochranehandbook.org.

Hopewell, S., Clarke, M., Moher, D., Wager, E., Middleton, P., Altman, D. G., Schulz, K. F., \& CONSORT Group (2008). CONSORT for reporting randomised trials in journal and conference abstracts. Lancet (London, England), 371(9609), 281-283. https://doi.org/10.1016/S0140-6736(07)61835-2

Hróbjartsson, A., Emanuelsson, F., Skou Thomsen, A. S., Hilden, J., \& Brorson, S. (2014). Bias due to lack of patient blinding in clinical trials. A systematic review of trials randomizing patients to blind and nonblind sub-studies. International journal of epidemiology, 43(4), 1272-1283. https://doi.org/10.1093/ije/dyu115

Lefebvre, C., Manheimer, E., \&Glanville, J. (2011). Chapter 6.4. Designing Search strategies. In: Higgins, J. P. T., Green, S. (2012). Cochrane Handbook for Systematic Reviews of Interventions, Version, 5.1.0 [Internet]. The Cochrane Collaboration. http://handbook.cochrane.org/.

Liberati, A., Altman, D. G., Tetzlaff, J., Mulrow, C., Gøtzsche, P. C., Ioannidis, J. P., Clarke, M., Devereaux, P. J., Kleijnen, J., \& Moher, D. (2009). The PRISMA statement for reporting systematic reviews and meta-analyses of studies that evaluate health care interventions: explanation and elaboration. PLoS medicine, 6(7), e1000100. https://doi.org/10.1371/journal.pmed.1000100

Moustgaard, H., Bello, S., Miller, F. G., \& Hróbjartsson, A. (2014). Subjective and objective outcomes in randomized clinical trials: definitions differed in methods publications and were often absent from trial reports. Journal of clinical epidemiology, 67(12), 1327-1334. https://doi.org/10.1016/j.jclinepi.2014.06.020 
Myasoedova, E., Davis, J. M., 3rd, Crowson, C. S., \& Gabriel, S. E. (2010). Epidemiology of rheumatoid arthritis: rheumatoid arthritis and mortality. Current rheumatology reports, 12(5), 379-385. https://doi.org/10.1007/s11926-010-0117-y

Pradhan, E. K., Baumgarten, M., Langenberg, P., Handwerger, B., Gilpin, A. K., Magyari, T., Hochberg, M. C., \& Berman, B. M. (2007). Effect of Mindfulness-Based Stress Reduction in rheumatoid arthritis patients. Arthritis and rheumatism, 57(7), 1134-1142. https://doi.org/10.1002/art.23010

Rosenkranz, M. A., Davidson, R. J., Maccoon, D. G., Sheridan, J. F., Kalin, N. H., \& Lutz, A. (2013). A comparison of min dfulness-based stress reduction and an active control in modulation of neurogenic inflammation. Brain, behavior, and immunity, 27(1), 174-184. https://doi.org/10.1016/j.bbi.2012.10.013

Singh, J. A., Saag, K. G., Bridges, S. L., Jr, Akl, E. A., Bannuru, R. R., Sullivan, M. C., Vaysbrot, E., McNaughton, C., Osani, M., Shmerling, R. H., Curtis, J. R., Furst, D. E., Parks, D., Kavanaugh, A., O'Dell, J., King, C., Leong, A., Matteson, E. L., Schousboe, J. T., Drevlow, B., \& McAlindon, T. (2016). 2015 American College of Rheumatology Guideline for the Treatment of Rheumatoid Arthritis. Arthritis \& rheumatology (Hoboken, N.J.), 68(1), 1-26. https://doi.org/10.1002/art.39480

Solati, K., Mousavi, M., Kheiri, S., \& Hasanpour-Dehkordi, A. (2017). The Effectiveness of Mindfulness-based Cognitive Therapy on Psychological Symptoms and Quality of Life in Systemic Lupus Erythematosus Patients: A Randomized Controlled Trial. Oman medical journal, 32(5), 378-385. https://doi.org/10.5001/omj.2017.73

Stone P. W. (2002). Popping the (PICO) question in research and evidence-based practice. Applied nursing research: ANR, 15(3), 197-198. https://doi.org/10.1053/apnr.2002.34181

Strand, E. B., Zautra, A. J., Thoresen, M., Ødegård, S., Uhlig, T., \& Finset, A. (2006). Positive affect as a factor of resilience in the pain-negative affect relationship in patients with rheumatoid arthritis. Journal of psychosomatic research, 60(5), 477-484. https://doi.org/10.1016/j.jpsychores.2005.08.010

Teasdale, J. D., Moore, R. G., Hayhurst, H., Pope, M., Williams, S., \& Segal, Z. V. (2002). Metacognitive awareness and prevention of relapse in depression: empirical evidence. Journal of consulting and clinical psychology, 70(2), 275-287. https://doi.org/10.1037//0022-006x.70.2.275

van der Heijde, D. M., van 't Hof, M. A., van Riel, P. L., Theunisse, L. A., Lubberts, E. W., van Leeuwen, M. A., van Rijswijk, M. H., \& van de Putte, L. B. (1990). Judging disease activity in clinical practice in rheumatoid arthritis: first step in the development of a disease activity score. Annals of the rheumatic diseases, 49(11), 916-920. https://doi.org/10.1136/ard.49.11.916

Veehof, M. M., Oskam, M. J., Schreurs, K., \& Bohlmeijer, E. T. (2011). Acceptance-based interventions for the treatment of chronic pain: a systematic review and meta-analysis. Pain, 152(3), 533-542. https://doi.org/10.1016/j.pain.2010.11.002

Witek-Janusek, L., Albuquerque, K., Chroniak, K. R., Chroniak, C., Durazo-Arvizu, R., \& Mathews, H. L. (2008). Effect of mindfulness based stress reduction on immune function, quality of life and coping in women newly diagnosed with early stage breast cancer. Brain, behavior, and immunity, 22(6), 969-981. https://doi.org/10.1016/j.bbi.2008.01.012

Tang, Y. Y., Ma, Y., Wang, J., Fan, Y., Feng, S., Lu, Q., Yu, Q., Sui, D., Rothbart, M. K., Fan, M., \& Posner, M. I. (2007). Short-term meditation training improves attention and self-regulation. Proceedings of the National Academy of Sciences of the United States of America, 104(43), 17152-17156. https://doi.org/10.1073/pnas.0707678104

Young, L. A. (2011). Mindfulness meditation: a primer for rheumatologists. Rheumatic diseases clinics of North America, 37(1), 63-75. https://doi.org/10.1016/j.rdc.2010.11.010

Zangi, H. A., Mowinckel, P., Finset, A., Eriksson, L. R., Høystad, T. Ø., Lunde, A. K., \& Hagen, K. B. (2012). A mindfulness-based group intervention to reduce psychological distress and fatigue in patients with inflammatory rheumatic joint diseases: a randomised controlled trial. Annals of the rheumatic diseases, 71(6), 911-917. https://doi.org/10.1136/annrheumdis-2011-200351

Zautra, A. J., Davis, M. C., Reich, J. W., Nicassario, P., Tennen, H., Finan, P., Kratz, A., Parrish, B., \& Irwin, M. R. (2008). Comparison of cognitive behavioral and mindfulness meditation interventions on adaptation to rheumatoid arthritis for patients with and without history of recurrent depression. Journal of consulting and clinical psychology, 76(3), 408-421. https://doi.org/10.1037/0022-006X.76.3.408 